\title{
Macedonian Language
}

National Cancer Institute

\section{Source}

National Cancer Institute. Macedonian Language. NCI Thesaurus. Code C154028.

A South Slavic language spoken principally in the Republic of Macedonia and by the Macedonian diaspora. 